\title{
An Assessment on Application of Indigenous Knowledge as Disaster Risk Reduction Strategies in Kutubdia, Cox's Bazaar, Bangladesh
}

\author{
Samshad Nowreen ${ }^{1}$ and Md. Mohiuddin ${ }^{2}$ \\ ${ }^{1}$ Department of Tourism and Hospitality Management, Dhaka University, Dhaka-1000, Bangladesh \\ ${ }^{2}$ Department of Geography and Environment, Jagannath University, Dhaka-1100, Bangladesh
}

(Received: 15 December 2016; Accepted: 19 February 2017)

\begin{abstract}
This research investigates how indigenous knowledge helps to reduce disaster risks in the coastal areas of Bangladesh, specifically in the study area of Kutubdia, Cox's Bazaar. The location of the coastal area of Bangladesh is funnel shaped which is regarded as one of the most vulnerable cyclone-prone regions in the world because of its location and physiography. Almost every year coastal people experiences this nature induced devastation and loses their lives and property. However, to cope with this type of natural calamity and minimize their loss, coastal people apply their inherited practical knowledge that has been aimed to explore by this research. To conduct this research three types of survey methods has been used: primary data were collected using Participatory Rural Appraisal (PRA) tools, Focus Group Discussion(FGD) and semi-structured questionnaire survey. First of all, the study explored interesting house construction practices, techniques and protection maneuvers those reflect the ideas of indigenous knowledge of coastal people as primitive adaptation strategies to the cyclone disaster. It has also been found that the other indigenous practices like early cyclone warning system from nature including animal behavior and weather condition. The dynamics of cyclone: classification, occurrence and affected scenario in the coastal region have been identified for the Cox's Bazaar region.
\end{abstract}

Key words: Cyclone, Coastal area, Indigenous knowledge, DRR, Kutubdia

\section{Introduction}

The coastal area in the world are highly populated where $40 \%$ people of global population is living within 100 kilometers coastline ${ }^{1}$. Bangladesh is a low-lying and one of the most susceptible countries in the world to cyclone ${ }^{2}$. The Bay of Bengal is anideal place for the development of tropical cyclones; about 149 cyclones have struck Bangladesh coast between 1891 and 1998. Three ruthless cyclones (November 1970, April 1991 and May 1997) with wind speed near about $220 \mathrm{~km} / \mathrm{h}$ that generated surges more than $4 \mathrm{~m}$ high-slapped Bangladesh since $1970^{3}$. Tropical cyclones make destructive effects on poor countries ${ }^{4}$. The high and extreme waves are one of the reasons to the damage of coastal areas. The losses can generally be divided into two types: the damage due to the demolition of houses, infrastructure and other properties (direct loss) and the damage in output by reason of impermanent power cut in production. Despite of being poor and vulnerable at the context of their position for different kinds of hazard, coastal people cope with the hazardous and disastrous environment by their earned knowledge from nature (indigenous knowledge) ${ }^{5}$.

Utilizing indegenous knowledge could be the best policy for disaster management and risk reduction in the coastal regions ${ }^{6}$. Vulnerable people of coastal area cope with the adverse situation through their own innovations and techniques ${ }^{7}$. Indigenous knowledge is transmitted from one generation to the next and coastal people of Bangladesh have a plenteous knowledge because of frequent cyclone in the Bay of Bengal ${ }^{8}$. It is necessary to gather local knowledge to mitigate the damage that people respond to different disasters occurred around them ${ }^{9}$.This knowledge is valuable for coastal community in reducing damage caused by disaster $^{10}$. Currently, people are applying indigenous techniques more to overcome the cyclonic damages ${ }^{11}$. Evidence from the literature depicts that the death caused by cyclone has decreased because of modern methods including early warning and preparedness but economic losses has increased due to damage of properties including weak house structures, crops and other properties ${ }^{12}$. Against the

\footnotetext{
"Author for correspondence. e-mail: nowreen22@gmail.com
}

backdrop, this study highlights the dynamics of cyclone in particular zones:origin and damages caused by cyclone induced disaster. However, this paper investgates the frequent losses created by cyclones at Kutubdia in Cox's Bazaar, Bangladesh and identifies various indegenous knowledge applied for disaster risk reduction in the study area.

\section{Objectives of the study}

Main objective of this study is to identify how indigenous knowledge is used to adapt with the natural disaster specifically cyclone in a particular area. Furthermore, objectives could be mentioned as following:

To explore different indigenous knowledge for adapting cyclone induced hazard.

\section{Methodologiesand Study Area}

\section{Methods and Materials}

The study was carried out from 12 December to 24 December in 2010 by applying two methods: Focus Group Discussion (FGD) and Semi-structure questionnaire survey. FGD is a technique used to in the study consisting of a group of people (eight or nine people) with similar socio-economic background, beliefs and activities that has been applied to practice their knowledge and experience during natural disasters. The study has been as certained local terms and strategies to mitigate the damages from diversified ideas of coastal people by two (2) FGD's, One was organized in Baraghop (Upazila sadar) including chairmen of six unions of the Upazila, and another was in Ali Akbar Dail with local people. Semi-structured questionnaire in Kutubdia Upazila under Cox's Bazaar district where three hundred (300) households were randomly selected among 18,093 households for questionnaire survey from 6 unions based on their population, household sizes and regional condition. They were surveyed at their house and working place at three particular times - in the early morning $(6-8 \mathrm{am})$, in the lunch time (12-4pm) and in the evening (5-7pm). The questionnaire was prepared having questions related to 
socio-economic condition, dynamics of cyclone in coastal region and different indigenous knowledge. Two Likert charts (scale ranges from 0-5) were used to identify animals' susceptibility towards cyclone forecast and human's perception as well. In the Likert chart 0 meant strongly disagree and 5 meant strongly agree towards the issue asked to the participants. Where 2.5 meant neutral value. The surveyed households were farmers, fishermen, NGO and Government officers, businessmen, and public representatives (Union Parishad Chairman and Members).

Study Area

Kutubdia, an island Upazila of Cox's Bazaar districts the study area for this research which is situated in the coastal eastern part of Bangladesh. The study area comprises of an area of 2,491.86 sq. $\mathrm{km}$. It is located near the basin of Matamuhuri and Shango. Banskhali Upazila of Chittagong Zila borders the Upazila to the north, southeast is bounded by Moheskhali Upazila of Cox's bazaar district and rest of the area is surrounded by the Bay of Bengal ${ }^{13}$ (BBS, 2011). The island is detached by 400 -meter wide channel (Kutubdia Channel) from the mainland (Fig. 1).

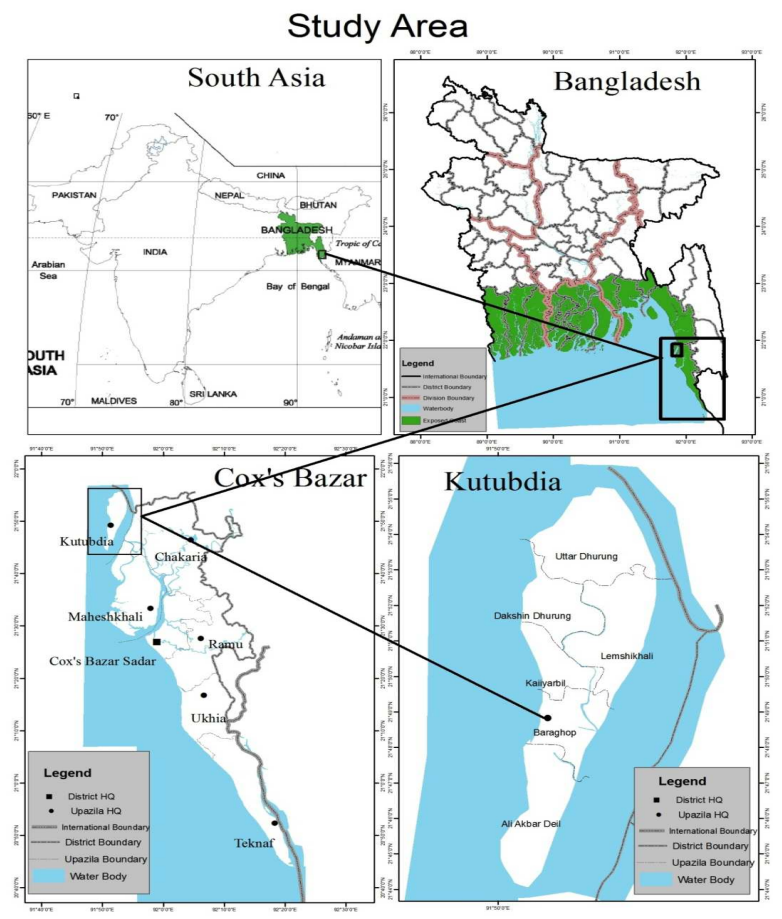

Fig.1. Study Area, Kutubdia

Source: Authors generated from district map

The communication between Kutubdia to mainland is by boat - Engine boat, Danish boat (High Speedy Machine Boat) round the year. People of the area are very poor, most of the people of study area involve in agriculture mainly salt cultivation.

\section{Results and Discussions}

The frequency and magnitude of hydro-metrological hazards and disasters are gradually increasing such as tsunami in 2004, hurricane Katrina in 2005 and SIDR in 2007 . The huge number of causalities is created by cyclone associated with even $6 \mathrm{~m}$ storm surges, which is pretty usual in the coastal areas. Generally cyclones develop during SeptemberNovember and March-May in the Bay of Bengal ${ }^{14}$ (Singh, 2000). According to 40 years periodical study by Joshep ${ }^{15}$, maximum cyclone occurred during 1930-70 with lower magnitude and minimum occurred during 1950-90 with maximum magnitude in the Bay of Bengal. Table 1 shows major cyclones occurrence from 1991-2007 and death of people by the cyclone.

Table 1. List of Major Cyclones Occurred in the Bay of Bengal

\begin{tabular}{|l|l|l|l|}
\hline Date & $\begin{array}{l}\text { Maximum } \\
\text { wind } \\
\text { speed } \\
(\mathrm{km} / \mathrm{h})\end{array}$ & $\begin{array}{l}\text { Maximum } \\
\text { Surge } \\
\text { height }(\mathrm{m})\end{array}$ & $\begin{array}{l}\text { Death } \\
\text { (people) }\end{array}$ \\
\hline $9^{\text {th }}$ May 1961 & 160 & 3.0 & 11,468 \\
\hline $28^{\text {th }}$ May 1965 & 203 & 3.8 & 11,520 \\
\hline $12^{\text {th }}$ Nov 1970 & 222 & 10.6 & $3,000,000$ \\
\hline $25^{\text {th }}$ May 1985 & 154 & 4.3 & 4,264 \\
\hline $29^{\text {th }}$ Nov 1988 & 160 & 4.4 & 1498 \\
\hline $29^{\text {th }}$ April 1991 & 225 & 6.1 & 138,000 \\
\hline $2^{\text {nd }}$ May 1994 & 215 & 3.3 & 188 \\
\hline $19^{\text {th }}$ May 1997 & 225 & 4.6 & 126 \\
\hline $26^{\text {th }}$ Sep 1997 & 150 & 3.0 & 155 \\
\hline $15^{\text {th }}$ Nov 2007 & $220-250$ & 6.0 & 3,500 \\
\hline
\end{tabular}

\section{Source: Karim, 2008}

Major cyclones hit coastal area in 1970, 1991, 2007 in which remarkable destruction was in 1970 when 3,000,000 human died followed by 1991 cyclone caused causalities of 138,000 (Table1). It is also interesting that having similar intensity cyclones before 1970's people used to die 100 times more than after 90s. People used more indigenous knowledge with advanced weather forecasting along with traditional weather warning from the environment. Therefore, rate of devastation decreased in the area. Moreover, even after having cyclone up to $250 \mathrm{~km} / \mathrm{hr}$ speed and storm surge $6 \mathrm{~m}$ heights 3,500 people died compared to similar cyclone in 1991 more than 0.13 million people died.

\section{Cyclone Hit and Structural Capacity}

The cyclone that struck the Bangladesh coast during the night on 29 April 1991 was one of the most devastating one. It had a width more than the size of Bangladesh. Each and every people had to tolerate the adversity of that cyclone in Kutubdia. Most of the affected houses were katcha (made up of mud)(58.47\%) and jhupri (made of bamboo stick, straw and polythene) $(39.79 \%)$. According to the field survey $60.33 \%, 64.40 \%$ and $26.33 \%$ people of Kutubdia were affected in 1996, 1997 and 2007 respectively (Fig. 2). However, intensity of devastating effects on houses decreased from 1991 to 2007 very sharply (Table 2). Total affected houses decreased from 300 to around 75 from 1991 to 2007 cyclone impacts. Household heads mentioned as they used indigenous knowledge for constructing houses, it helped them to reduce house damages. 
Table 2. Cyclone Affected Houses by Type and Time

\begin{tabular}{|c|c|c|c|c|c|c|c|c|}
\hline \multirow{3}{*}{ 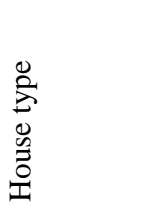 } & \multicolumn{8}{|c|}{ Type of house affected by year } \\
\hline & \multicolumn{2}{|c|}{1991} & \multicolumn{2}{|c|}{1996} & \multicolumn{2}{|c|}{1997} & \multicolumn{2}{|r|}{2010} \\
\hline & $\mathrm{N}$ & $\%$ & $\mathrm{~N}$ & $\%$ & $\mathrm{~N}$ & $\%$ & $\mathrm{~N}$ & $\%$ \\
\hline $\begin{array}{l}\text { Semi- } \\
\text { pucca }\end{array}$ & 5 & 1.7 & & & & & & \\
\hline Katcha & 169 & 58.5 & 94 & 31.8 & 101 & 34.2 & 32 & 10.7 \\
\hline $\begin{array}{l}\text { Katcha } \\
\text { (Jhupri) }\end{array}$ & 115 & 39.8 & 84 & 28.5 & 89 & 30.2 & 47 & 15.7 \\
\hline $\begin{array}{l}\text { Affected } \\
\text { Total }\end{array}$ & 289 & 100 & 178 & 60.3 & 190 & 64.4 & 79 & 26.3 \\
\hline $\begin{array}{l}\text { Household } \\
\text { Total }\end{array}$ & 289 & 100 & 295 & 100 & 295 & 100 & 300 & 100 \\
\hline
\end{tabular}

Source: Field Survey, $2010 *$ N=Number of Household Head

Scenario of Losses and Damages Over the Years by Cyclone

On the basis of respondents, the most memorable and devastating cyclones and storm surges affected were in 1991, 1996, 1997 and 2010. Although the magnitudes of disasters were not same every time, dwellers of Kutubdia remembered those cyclone because of their sever loss. Most importantly, cyclone of 1991 affected all of the people of Kutubdia in many ways. The people lost their resources including crops, saltpans, houses and livestock etc.; they also lost huge capital (cash)(Table2).

Table 3. Frequent Loss and Damages Over the Years

\begin{tabular}{|c|c|c|c|c|c|c|c|c|}
\hline \multirow[t]{2}{*}{ Years } & \multicolumn{5}{|c|}{$\begin{array}{l}\text { Cyclone Induced Damages } \\
\text { (BDT) }\end{array}$} & \multirow[b]{2}{*}{ 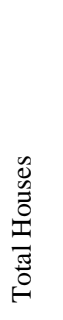 } & \multirow[b]{2}{*}{ 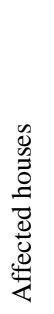 } & \multirow[b]{2}{*}{ 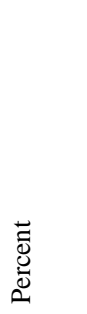 } \\
\hline & $\begin{array}{l}8 \\
\delta \\
\text { î } \\
0\end{array}$ & $\begin{array}{l}8 \\
8 \\
0 \\
i n \\
i \\
8 \\
i\end{array}$ & $\begin{array}{l}8 \\
8 \\
i \\
i \\
8 \\
8 \\
i\end{array}$ & $\begin{array}{l}8 \\
8 \\
8 \\
8 \\
\frac{1}{8} \\
i \\
i\end{array}$ & $\begin{array}{l}+ \\
8 \\
8 \\
8 \\
8\end{array}$ & & & \\
\hline 1996 & 20 & 112 & 40 & 6 & - & 295 & 178 & 60.33 \\
\hline 1997 & 12 & 67 & 89 & 20 & 2 & 295 & 190 & 64.41 \\
\hline 2007 & 7 & 47 & 25 & - & - & 300 & 79 & 26.33 \\
\hline
\end{tabular}

Source: Field Survey, $2010 *$ N=Number of Household Head

The destruction of 1991 influenced all the residents of the area fully and it washed out the katcha house structures. Some houses were damaged partially, people lost their lives, and properties. Considering the brutal hit and colossal loss, the 1991 disaster was the worst. Over the years, as the figure shown in the table 3 , the damages of houses in terms of money decreased substantially from 1996 to 2007; causalities were little because of applying indigenous knowledge by coastal people(Table 3 ). The declining trend of monetary loss could also be ascribed to the application of indigenous knowledge.

\section{Indigenous Knowledge Applied by Coastal People}

Lower income, poor housing and inadequate sanitation have made coastal people more vulnerable ${ }^{16}$. Hence, indegenous knowledge could bethe best tools for disaster mangement ${ }^{6}$. As it is not possible to make or implement plans of policies without knowing the real scenerio and staying in the affected area. It is originated within the sourounding environment that is influenced by culture and nature and gained by experience and practice ${ }^{17}$. Coastal community uses their indigenous knowledge to with stand against the cyclone damages like house building;cyclone warning and so on; and the remarkable information is portreyed below on the basis of the respondent's importance.

\section{Indigenous Knowledge in Housing Practice}

The prime concern of the study was to observe the coping strategy against the adverse situation against cyclone, which focuses on housing practice of the coastal people.

\section{Housing Structure to Reduce the House Damage}

Near about $46 \%$ people of coastal area take shelter in cyclone shelters during cyclone and one third of rest of them applies indigenous knowledge such as house building techniques ${ }^{18}$. Field study found that some houses are built close to the embankments in such a way that the top of the house is elevated to same height of the embankment to save the roof or structure from the on slaught of the disaster. The height of the roof of a house are 3/3.5 feet from the ground (Fig-2 \& 3), however, lower height could be of 2/3 feet from the ground where in general house structure height of roofs are 10/12 feet height from the ground level.

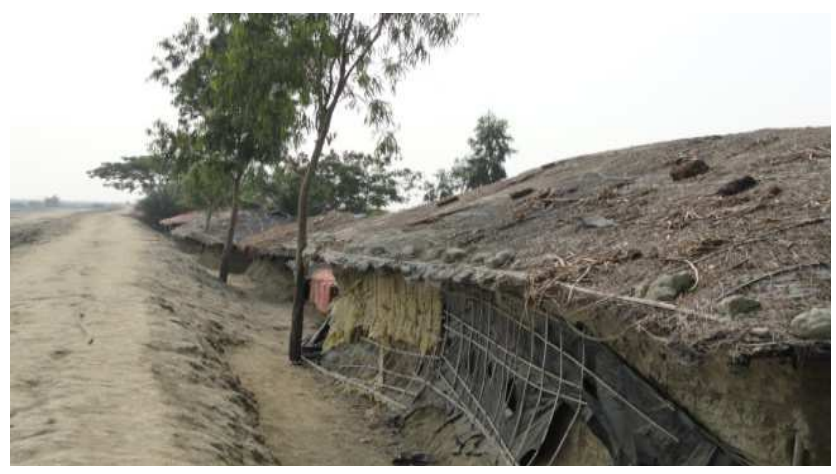

Fig. 2. Location of House by Side of Embankment, Kutubdia, 2010 


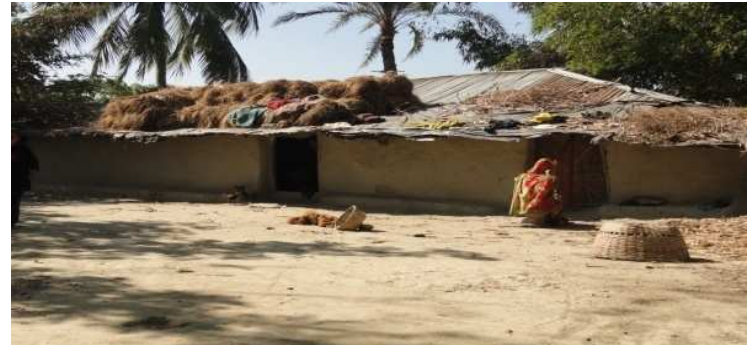

Fig. 3. The Houses are Located on the Upper Land, Kutubdia, 2010

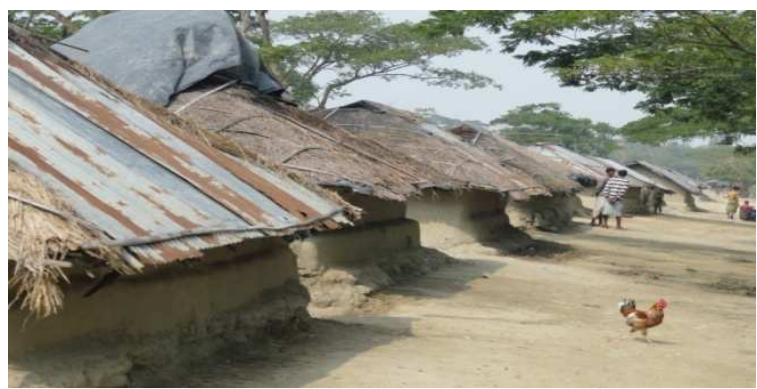

Fig. 4. Cho-chala Houses with Lower Height, Kutubdia, 2010

Some structures have Cho-chala (four-sided roofed) that protects the houses from cyclonic wind from different directions and these types of roofs have height lower than two-sided roofed houses. Hence, these roofs protect the house from speedy wind (Fig. 4). These types of houses are mostly found in Ali Akbar Dail and Uttar Dhurangunion in kutubdia.

The Housing Structure on the Upper Land to Save from Storm Surge

In Bangladesh, people have a propensity to build up their house unit on the elevated land or clay platform with the intention that water cannot reach the plinth level in tidal surge in flood prone area ${ }^{19,}{ }^{20}$.People take shelter on the embankment to save their lives during disasters; sometimes they build up house structure on the upper land ${ }^{18}$. Those houses are located on the upper land to protect the damages from the storm surge (Fig. 2). Approximately 5\% houses are built up on the upper land those are very close to the coast for example- part of Kairbil and Baroghop union, Kutubdia.

\section{Vegetation Coverage to Reduce Cyclonic Speed}

From the study it is found that the Green belt or vegetation coverage is important for the coastal areas since they are supportive for housing to reduce the impact of the cyclone on coastal belt in monsoon period. The cyclonic wind comes from south-eastern part of the Bay of Bengal. So, coastal people and government use to plant the trees that are saline tolerant and help to make weaker the cyclonic wind speed. These trees protect the settlement in the southern part of the Upazila (Fig. 5 \& 6).

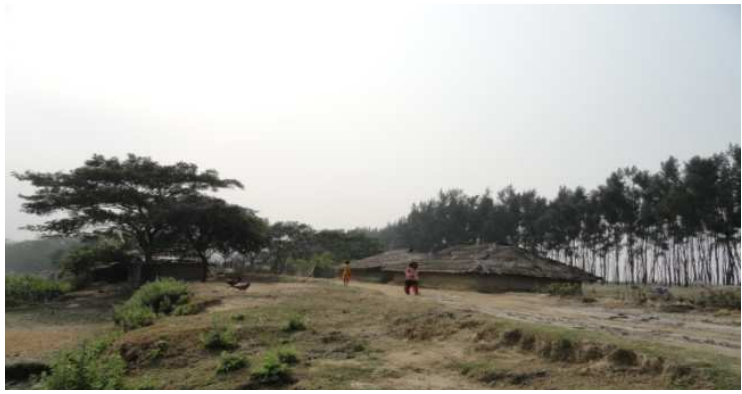

Fig. 5. Vegetation Coverage Outer Side of Housing

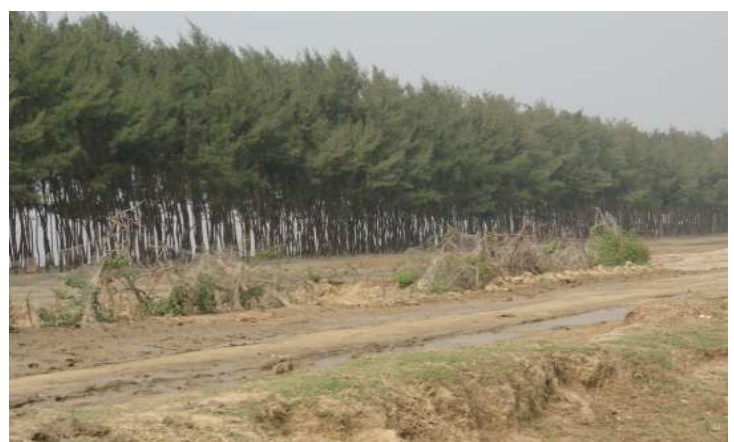

Fig. 6. Vegetation Coverage as Coastal Green Belt

Application of Indigenous Knowledge in Core House to Mitigate the Damages

It is observed that in the coastal areas, the small houses (core house) are built inner side of main house for saving their food, lives and property. In Zimbabwe, this special type of house is called 'Dura' ${ }^{19}$. During the disaster the main houses may be damaged but the core houses may sustain even after disaster. When disaster starts hitting, coastal people keep their valuable goods in the core houses and some

(Heavy and wet things) are put into the ground (Fig. 7).

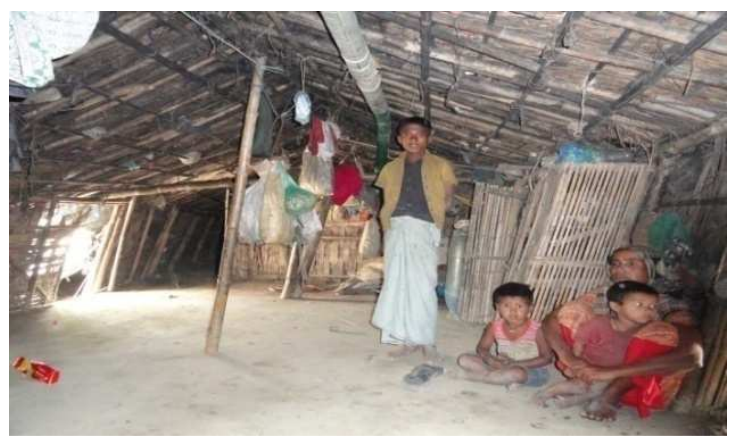

Fig. 7. Core House Safety, Ali akber Dail,

\section{Salt Saving Techniques}

The prime occupation of the people (75\%) of the study area is salt cultivation. Most of the time they involve in salt production field except rainy season. Coastal people produce salt using their own technology. But they need to reserve the salt during or before the disaster. So, they keep salt into the hole at the corner of salt field during disaster so that it can be used later on (Fig. 8). 

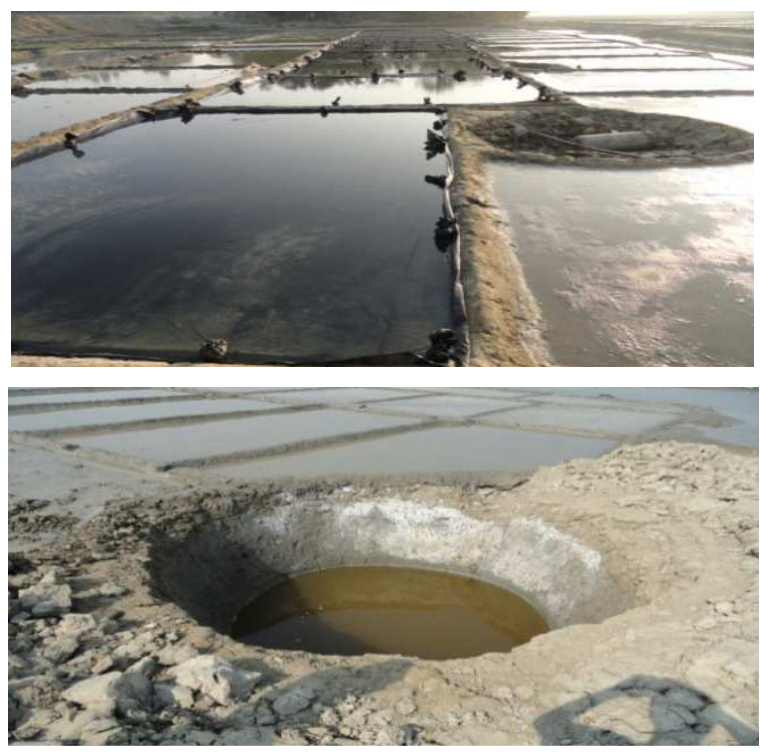

Fig. 8. Salt Production and Self-Technology

Coping Strategies to Conserve Food, Water and Necessary Things

Scarcity of food and water during hazard(pre and post)is very common phenomena in disaster-affected area. Food and water are prime concern to the household head during disaster period. The storage of food and water is a challenging issue for the disaster prone coastal area. Coastal people prefer to use polythene to keep dry food, grain and precious things into the hole. Sometime they reduce the number of regular meals per day by taking boiled rice (Murior Chira), wild fruits and leaves. The primary need of the affected people is to make sure for pure drinking water. The field survey confirm that $93 \%$ people of the study area use tube well water but some $(30 \%)$ tube well are lower positioned those are not useable during hazardous situation. Coastal people use plastic container to reserve water during the disaster.

\section{Application of Indigenous Knowledge for Early Warning Practice}

Indigenous knowledge is helpful to understand various environmental phenomena. It is based on their culture and beliefs related to their experience. Coastal people gain this knowledge from nature like the behavior of environmental elements (air, water, temperature) or animals, insects and species.

\section{Animal Behavior (excluding human)}

Indigenous knowledge is progressively developed in local areas and thus sustainable adaptation strategies developed over time to tackle adverse environment. Acehnese people (Indonesia) use song and poem not only for cultural performance but also to educate community and share information for concerning about disaster. A part of the lyrics from traditional song of Aceh language bring the message about tsunami disasters such aslaotmanyangmeugunong means 'Water Sea reach the Mountain', Like wise human, animals as well as insects also use some signals to realize upcoming danger. Animals are much more sensitive than human being because they can sense the surrounding environment before the cyclone hit and run for safe shelter. Some important animals, which can sense upcoming natural disasters, are ants, fish, dog and frog. High occurrence of ant indicates the heavy rain, non-flying movement of termites indicates prolonged the dry season. During the study it was found that sometimes ant's behavior is the most effective than dogs, fish and frog. However, behavior of fish is moderate from jumping over the water and spontaneous moving. Without rainy season, frog is not active to respond because before winter (November) it goes into hibernation. Lastly, barking of dog is the most important sources for year round signaling before cyclone occurrence like other danger (Table 4).

A reliability test was carried out to observe the animal special behavior before cyclone of four animals and insects, which were free from random error and to show internal consistency in each dimension $^{21}$ (Table 3 ). The alpha value that approaches 1.0 show high internal consistency reliability while a value less than 0.6 is considered to be weak ${ }^{22}$; weak values were eliminated. In all, Cronbach's alpha values for the behavior pattern ranged 0.89 . This meant that the constructs were retained for further analysis.

Table 4. Animal Behavior before Cyclone

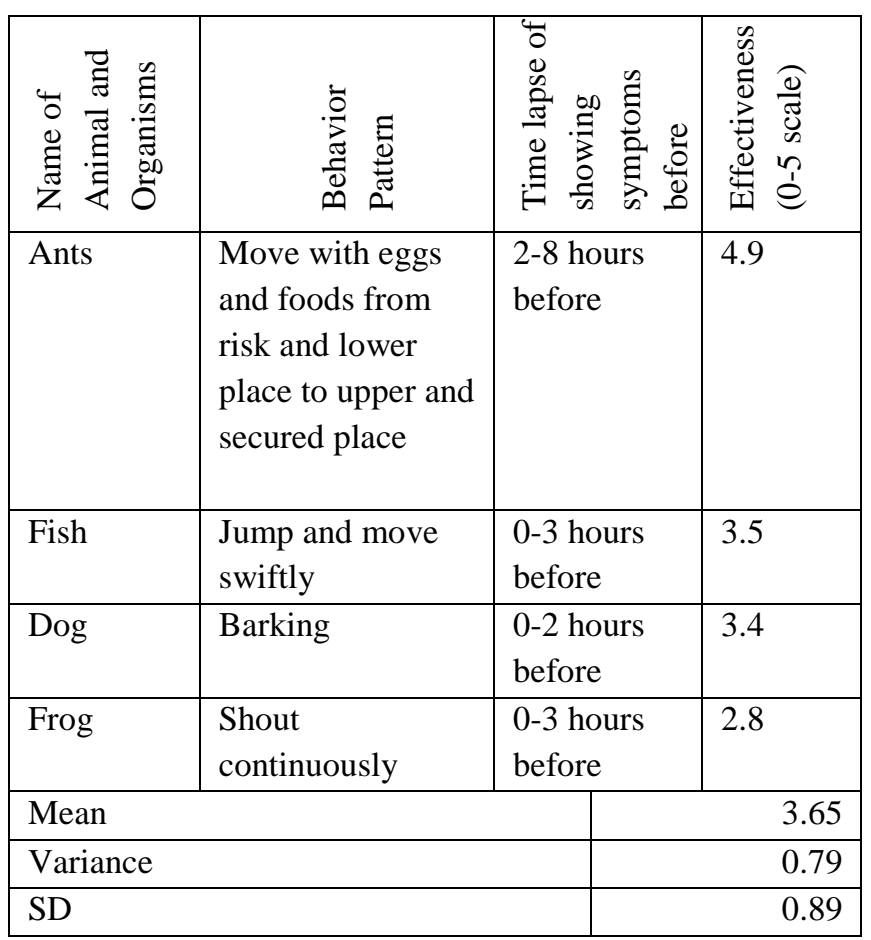

Source: Field Survey, 2010

From table 4 it is found that most of the animals in the study region highly respond to upcoming forecast and residents of those regions observe those each time. Ants' starts moving 2-8 hours before in a row to any safe upward land. Fishes jump spontaneously before occurrence of cyclone, which is also remarkable. The mean value of all the animals considered for observation such as ant, fish, dog and frog are 3.65 , which is strongly responsive to the circumstances. 
Furthermore, variance and standard deviation of the four values are 0.79 and 0.89 respectively which means they have very low variation among the results. Therefore, it is well understood that resident can understand when the cyclone is going to hit exactly from animal behavior as and take necessary steps to combat with the disaster.

\section{Sensation from Weather}

Weather condition can be felt by use the environmental indicators for example, change of weather elements, and behavior of flora and fauna. Various types of clouds (dark shadow) cloud in the sky and south-western wind before 812 hours signals the strong cyclone is most $^{7}$. According to the respondents of field survey, within strong wind blow sudden stop of wind blow and transforming area into very calm makes people understand something very bad in the environment goes to happen (Table 5). The mean value of these sudden changes in weather is 4.4 , which is very highly positive to the respondents. Hence, the variance is 0.286 that is negligible. Therefore, residents of that region could understand the intensity of cyclone from their prior experience.

\section{Table 5. Weather Behavior before Cyclone}

\begin{tabular}{|l|l|l|}
\hline Type of conditions & $\begin{array}{l}\text { Time of } \\
\text { Symptoms before } \\
\text { cyclone }\end{array}$ & $\begin{array}{l}\text { Effectiveness } \\
(0-5 \text { scale })\end{array}$ \\
\hline $\begin{array}{l}\text { Wind blow from } \\
\text { south-western } \\
\text { corner }\end{array}$ & $\begin{array}{l}\text { 8-12 hours } \\
\text { before }\end{array}$ & 4.8 \\
\hline $\begin{array}{l}\text { Nimbus cloud move } \\
\text { swiftly }\end{array}$ & $2-4$ hours before & 4.1 \\
\hline $\begin{array}{l}\text { Feeling of } \\
\text { temperature } \\
\text { fluctuation }\end{array}$ & $0-1$ hours before & 3.8 \\
\hline $\begin{array}{l}\text { Wind suddenly } \\
\text { stops blowing }\end{array}$ & $0-1$ hours before & 4.9 \\
\hline Mean & & \\
\hline Variance & & 0.86 \\
\hline SD & & \\
\hline
\end{tabular}

Source: Field Survey, 2010,Ahsan, 2007

\section{Conclusion}

The study has found people of that area are mostly involved in agriculture activities specifically salt cultivation and fishing. The research reveals two-thirds $(63.2 \%)$ of the coastal people earn poor(4000-5000 tk.) and build up weak houses structures $(94.67 \%)$ that are vulnerable due to location and regular hit by disaster mostly cyclone. Although they are lowincome holders and build up weak house structure, they use indigenous knowledge from nature to mitigate the damages. Indigenous knowledge exists in the coastal community that was found during field study. Indigenous knowledge is not static but very influential tool for disaster risk reduction. Over the decade, the causalities have been common due to cyclonic disturbance but at present, this rate has reduced because of the development of forecasting use of indigenous knowledge. Enough support is inadequate to mitigate cyclonic devastation although they have huge indigenous knowledge (local knowledge). Some recommendations are made to improve indigenous knowledge, and capacity to reduce risk and adapt to the adverse environment. Previous experienced from nature should be recorded, modified and upgraded to use for next disaster risk. Furthermore, free loan could be provided to the coastal people to erect disaster resilient house structures including multistoried building with communication facilities and house building techniques, should be given information adjusted with indigenous knowledge for preparedness and awareness in reducing disaster risk.

\section{References}

1. Fakhruddin, S.H.M., \& R. Juma, 2015. Coping with coastal risk and vulnerabilities in Bangladesh.

2. IPCC, 2007. Climate Change 2007: Impact, Adaptation and Vulnerability. Contribution of Working Group II to the Fourth Assessment Report of the IPCC. Cambridge University Press, UK, 976.

3. Emanuel, K.A., 2005. Increasing destructiveness of tropical cyclones over the past 30 years. Nature. 436, 686-688.

4. Landsea, C.W., B. A. Harper, et al., 2006. Can we detect trends in extreme tropical cyclones? 313, 452-454.

5. Parvin, G. A., Takahashi, F., Shaw R., 2008. Coastal hazards and community-coping methods in Bangladesh. J Coast Conserve, 12, no. 4,181-193.

6. Sayfwina, 2014. Recognizing Indigenous Knowledge for Disaster Management: Smong, Early Warning System from Simeulue Island, Aceh, The 4th International Conference on Sustainable Future for Human Security, Sustain, Procedia Environmental Sciences. 573 - 582.

7. Ahsan, M. M. \& M. Azam, 2007. Indigenous Knowledge and Cyclone Preparedness of a Remote Coastal Community in Bangladesh, indigenous people and Bangladesh environment, Bangladesh Poribesh Andolon (BAPA).

8. Khan, N. A. \& S. Sen, 2000. Popular Wisdom: indigenous knowledge and practices in Bangladesh. BARCIK. Lalmatia, Dhaka, 147-149.

9. UNISDR, 2007. Disaster occurrence: number of natural disasters registered in EMDAT. Retrieved from http://www.unisdr.org/disaster- statistics/occurrence-trendscentury.htm.

10. Warren, D.M., \& B. Rajasekaran, 1993. Putting local knowledge to good use. International Agricultural Development; 13, No. 4, 8-10.

11. Ahsan, M. M. \& M. Azam, 2007. Indigenous Knowledge and Cyclone Preparedness of a Remote Coastal Community in Bangladesh, indigenous people and Bangladesh environment, Bangladesh Poribesh Andolon (BAPA).

12. Raghavan, S. R., 2003. Trends in Tropical Cyclone Impact: A Study in Andhra Pradesh, India. Bulletin of American Meteorological Society, 84, 623.

13. BBS, 2011. District Statistics 2011: Cox's Bazar. Retrieved from:

http://203.112.218.65/WebTestApplication/userfiles/Image/Dist rict\%20Statistics/Cox\%60s\%20Bazar.pdf 
14. Singh, O. A., 2000. Changes in the Frequency of Tropical Cyclones. Meteorol. Atmos. Phys. 75, 11-20.

15. Joseph, P. A., 1999. Monsoon-rainfall and frequencies of monsoon depression and tropical cyclones of recent 100 years and an outlook for the first decades of the 21st century. Proceedings- TROPMET, 364-371. Indian Meteorological Society.

16. IPCC, 2001. Working Group II Report "Climate Change 2001: impacts, adaptation, and vulnerability". Intergovernmental Panel on Climate Change, Third Assessment Report Hazards 16, 181-202.

17. Baumwoll, J., 2008. The value of indigenous knowledge for disaster risk reduction: A Unique Assessment Tool for Reducing Community Vulnerability to Natural Disasters, Master Thesis, Vienna: Webster University.
18. Parvin, G. A., F. Takahashi, \& S. Rajib, 2009. Coastal Hazards and Community Coping Methods in Bangladesh, Journal of Coastal Conservation, 12(4), 181-193.

19. Manyena, S. B. et al., 2013. Indigenous Knowledge Coping Strategies and Resilience to Floods in Muzarabani, Zimbabwe, international journal of Disaster Risk reduction, 38-48.

20. Poul S. K. \& J. K. Routray, 2010. Flood proneness and coping strategies: the experience of two villages in Bangladesh, Disasters: 34, 489-508.

21. Pallant, J., 2005. SPSS Survival Manual: a Step-by-Step Guide to Data Analysis using SPSS for Windows version 12 (2nd Ed.). Sydney: Allen \& Unwin.

22. Sekaran, U., 2003, Research Methods for Business - A Skill Building Approach, $4^{\text {th }}$ ed., Wiley, New York, USA. 
